\|III!! 総説

\title{
食品污染カビ毒マイコトキシンの生体内 代謝と毒性発現
}

篻 内桃子, 福 原 守 雄*

国立衛生試験所・薬理部, *国立公衆衛生院・衛生薬学部

Toxicity and Metabolism of Food Contaminated Mycotoxins

Momoko Sunouchi and Morio Fukuhara*

Division of Pharmacology, National Institute of Hygienic Sciences ;

* Department of Pharmaceutical Sciences, The Institute of Public Health

はじめに

現在我が国では，食品の原料としてまた家畜の飼料として，多くの農産物を諸外国から輸入している。加工 食品も加えると，食料の対外依存度は極めて大きく，食料品の安全性に対しては，国の内外を問わず十分な注 意を払う必要があると思われる。

食料品の安全性を考慮する上で最も大きな問題の1つとして, 農産物もしくはその加工食品のカビ毒による 污染があげられる。特に輸入品のカビ毒污染は，その原産国の衛生状態を反映しており，これからますます問 題となってくると思われる。カビ (糸状菌) の第 2 次代謝産物のうちで, ヒトを含む高等動物に対して有害な 作用をひき起こすカビ毒（マイコトキシン）は，污染された食物を通して体内に䀧取され，肝等で代謝される が, 生成された代謝物の中には, 元のマイコトキシンより毒性の強いものがあることが知られている。

そこで本稿では, マイコトキシンの概要と, 既に知られている発癌物質の中で最も発癌性の強いとされるア フラトキシン $\mathrm{B}_{1}$ を例にとり, その生体内に扔ける代謝と毒性の発現について, 主として動物実験によるデー タを中心に述べてみたい。

\section{I. マイコトキシン}

マイコトキシンの主な原因菌としては, コウジカビの仲間であるAspergillus 属, アオカビの仲間である Penicillium 属, アカカビの仲間であるFusarium 属の 3 種があげられる。農産物などに付着した有害カビ類が, カビの繁殖に都合のよい気候条件や保存状態下でマイコトキシンを産生し，このマイコトキシンによって污染 された農産物を摂取したり,これを飼料とした家音の肉類やミルクなどを摂取した場合にヒトに有害な作用を 与える。またマイコトキシンは，一般的な加熱調理では分解されずに食品中に半分以上が残存するため, 加工 食品からもとトに摂取され得る゙。

表 1 に, 主なマイコトキシンとその有害作用, 産生カビと污染される食物との関係を, 図 1 に, マイコトキ シンの化学構造を示した。アフラトキシン $\mathrm{B}_{1}\left(\mathrm{AFB}_{1}\right)$ とアフラトキシン $\mathrm{G}_{1}, \mathrm{AFB}_{1}$ の前駆物質であることが知 られているステリグマトシスチン21, オクラトキシン $\mathrm{A}$ とパツリンには発癌性が報告されている。その中でも, $\mathrm{AFB}_{1}$ による発癌性は最も強いものの 1 つであり, ラットに拈ける発癌最小摃取量は, ステリグマトシスチン の約 $1 / 650$ であることが報告されている3!。 
表 1 主なマイコトキシンの種類と産生カビ, 污染される食料と有害作用

\begin{tabular}{|c|c|c|c|}
\hline マイコトキシン & 産 生 カ ビ & 污染される食料 & 有 害 作 用 \\
\hline アフラトキシン & $\begin{array}{l}\text { Aspergillus flavus } \\
\text { Aspergillus parasiticus }\end{array}$ & $\begin{array}{l}\text { とうもろこし, 米, 麦, } \\
\text { ピーナッツ, ナッツ類, } \\
\text { 香辛料, ミルク, チーズ }\end{array}$ & $\begin{array}{l}\text { Rey'se 症候群, 急性肝炎, } \\
\text { 肝癌 }\left(\mathrm{B}_{1} ; \text { ～ヒト), 肝癌 }\left(\mathrm{B}_{1},\right.\right. \\
\mathrm{G}_{1} \text {; ラット, サル), 肝 } \\
\text { 障害 }\end{array}$ \\
\hline ステリグマトシスチン & $\begin{array}{l}\text { Aspergillus versicolor } \\
\text { Aspergillus nidulans }\end{array}$ & とうもろこし, 米 & 肝障害, 肝癌（ラット） \\
\hline オクラトキシンA & $\begin{array}{l}\text { Aspergillus ochraceus } \\
\text { Penicillium virdicatum }\end{array}$ & 麦類, とうもろこし & $\begin{array}{l}\text { 肝および腎障害, 生殖障害, } \\
\text { 肝癌（マウス等） }\end{array}$ \\
\hline パッリン & $\begin{array}{l}\text { Penicillium patulum } \\
\text { Aspergillus clavatus }\end{array}$ & 小麦, りんごジュース & $\begin{array}{l}\text { 腎障害, 嘔吐（ウシ）, 皮 } \\
\text { 膚癌（動物） }\end{array}$ \\
\hline $\begin{array}{l}\mathrm{T}-2 \text { トキシン } \\
\text { (トリコテセン系トキシン) }\end{array}$ & Fusarium tricintum & 麦類, とうもろこし & $\begin{array}{l}\text { 嘔吐, 下痢などの胃腸障害, } \\
\text { 血液障害 }\end{array}$ \\
\hline ゼアラレノン & Fusarium graminearum & 麦類, とうもろこし & エストロゲン作用 \\
\hline リゼルギン酸（麦角毒素） & Claviceps purpurea & えん麦, 大麦, 小麦 & $\begin{array}{l}\text { 筋肉痤攣, 虚血性壊死（壊 } \\
\text { 疽）(ヒト） }\end{array}$ \\
\hline
\end{tabular}

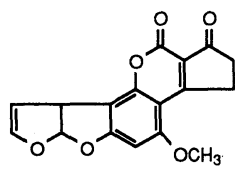

Aflatoxin $\mathbf{B}_{1}$

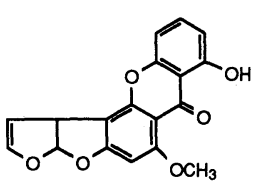

Sterigmatocystin

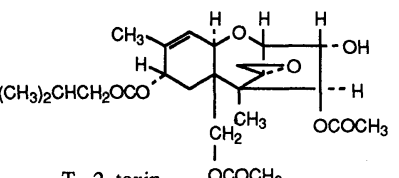

$\mathrm{T}-2$ toxin

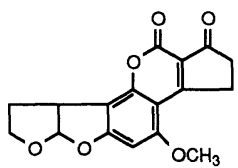

Aflatoxin $\mathrm{B}_{2}$

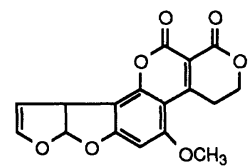

Aflatoxin $\mathrm{G}_{1}$

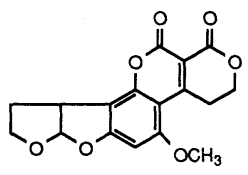

Aflatoxin $\mathrm{G}_{2}$
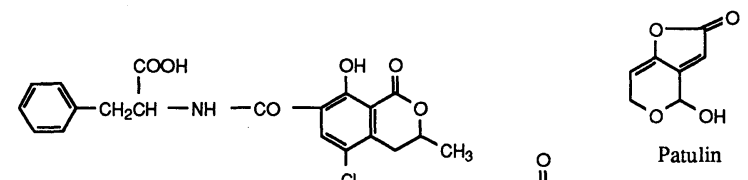

Patulin

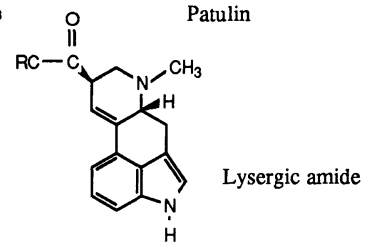

図 1 主なマイコトキシンの化学構造

マイコトキシンによって污染される農産物としては穀類が圧倒的に多く, 世界中の大部分の人々が穀類を主 食としていることを考えると, 污染がわずかであっても生涯にわたり慢性的にとり続けることになる。現在我 が国の農産物とその加工食品には，マイコトキシンによる污染，特に $\mathrm{AFB}_{1}$ に関してはガイドラインで定めら れている $10 \mathrm{ppb}$ 以上の污染事例はほとんどみられないが, 問題となるのは輸入農産物および香辛料等につい てである。自治体などによる監視が $\mathrm{AFB}_{1}$ による污染食品の排除に大きく貢献しているものの，污染食品が輸 


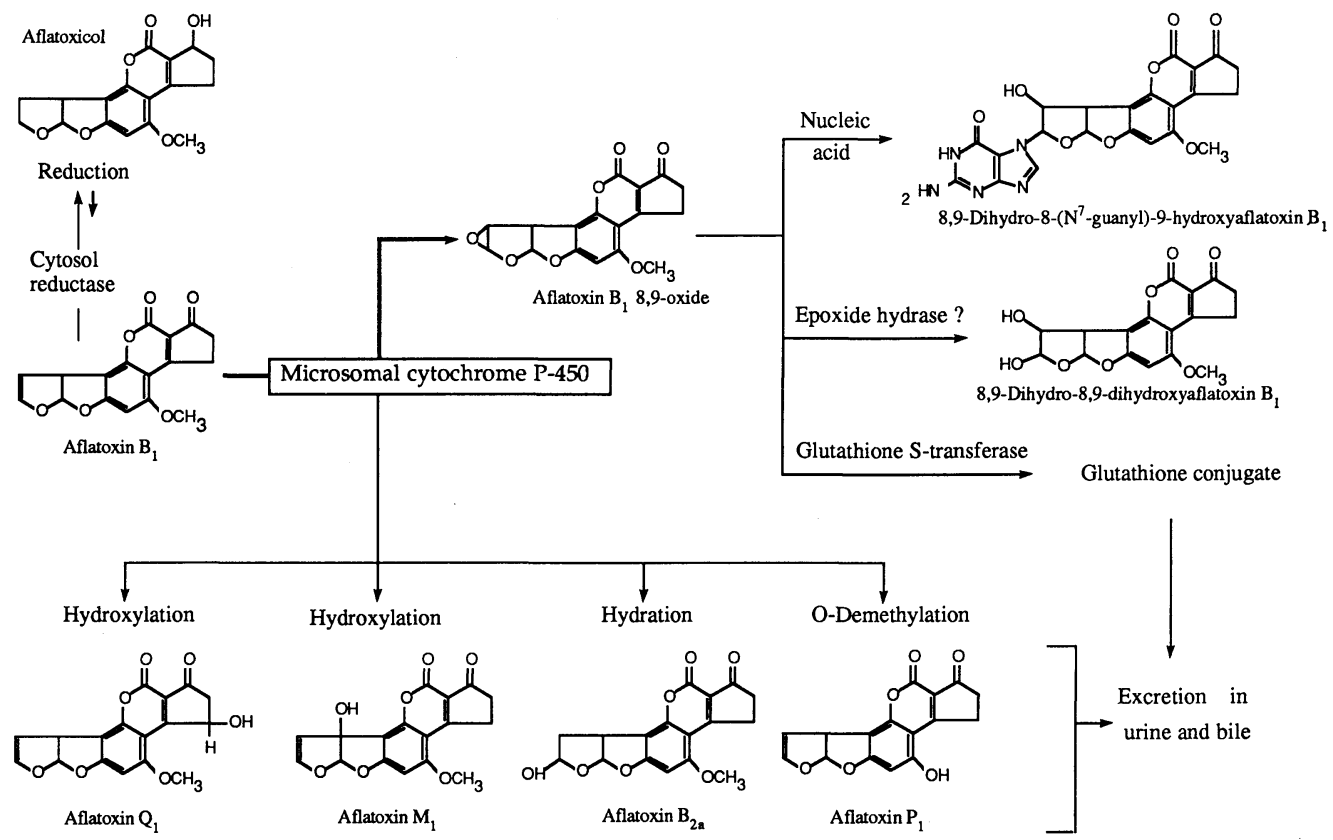

図 2 アフラトキシン $\mathrm{B}_{1}$ の代謝経路

入される可能性が無いとはいいがたい。

現実に1984年に，Tsuboi ら ${ }^{4}$ は，高圧液体クロマトグラフィーにより，普通の食生活をしている健康な日本 人男性の血清中に, $\mathrm{AFB}_{1}$ が $20 \sim 1,169 \mathrm{pg} / \mathrm{ml}$ の範囲で存在することを報告している。このことは，微量では あるが $\mathrm{AFB}_{1}$ による食料污染が身近なところで生じていることを示唆しており, 安全な食料確保のためのマイ コトキシン污染防御は, 人間の健康にとって極めて重要な課題であるといえる。

\section{II. アフラトキシン $\mathrm{B}_{1}$ の代謝経路}

アフラトキシンの研究は，1960年にイギリスで起こった“Turkey-X disease” ${ }^{5 /}$ に端を発している。この七 面鳥ひなの大量死事件の原因が，飼料として輸入されたとうもろこしのアフラトキシン污染によることが明ら かにされて以来, アフラトキシンに関する多くの研究が続けられてきた。アフラトキシンは 17 種類の存在が知 られている ${ }^{6}$ が, これらのうち, 毒性学的な観点から広く研究されているのはAFB である。

経口的に取り込まれた $\mathrm{AFB}_{1}$ のほとんどは腸管から吸収され7), 吸収された $\mathrm{AFB}_{1}$ は動物の肝薬物代謝酵素 系によって代謝活性化される ${ }^{81}$ 。 $\mathrm{AFB}_{1}$ は, 図 2 に示すように, 主に肝ミクロソームの薬物代謝酵素によって水

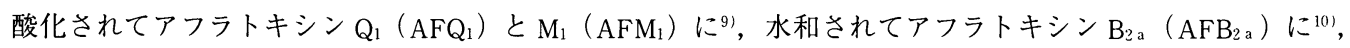
あるいは $\mathrm{O}^{-}$脱メチル化されてアフラトキシン $\mathrm{P}_{1}\left(\mathrm{AFP}_{1}\right)$ になる ${ }^{11}$ 。一方, 肝の可溶性上清における還元酵素 によってアフラトキコールが生成されるが, これはミクロソームのアフラトキコール脱水素酵素によって可逆 的に $\mathrm{AFB}_{1}$ となることが明らかにされている ${ }^{121} 。$

$\mathrm{AFB}_{1}$ の代謝物の変異原性は, $\mathrm{AFB}_{1}$ に比べて約 $1 / 5$ から $1 / 1,000$ と極めて低い ${ }^{131}$ が, $\mathrm{AFB}_{1}$ の強い変異原性 の原因となっている代謝活性化体は, $\mathrm{AFB}_{1}-8,9$-エポキシドであることがEssigmannらによって, 肝ミクロ ソームの存在下 $\mathrm{AFB}_{1}$ と DNA を反応させて生成される $\mathrm{AFB}_{1}$-DNA 結合体の $90 \%$ が, 8,9-dihydro-8- 
( $\mathrm{N}^{7}$-guanyl)-9-hydroxy-aflatoxin $\mathrm{B}_{1}\left(\mathrm{AFB}_{1}-\mathrm{N}^{7}-\mathrm{Gua}\right)$ であることから証明されている

\section{III. アフラトキシン $\mathrm{B}_{1}$ の代謝活性化}

$\mathrm{AFB}_{1}$ が代謝活性化されるのは, 主に肝のミクロソームに存在する薬物代謝酥素拉よびその本体であるチト クローム P-450（P-450）による。P-450については多くの総説があるので本稿では簡単に述べることにする が, P-450は, 肝をはじめとする主要臟器に存在する分子量が55,000前後で, 活性中心にプロトへムを有する へムたん白であり, 種々の分子種の存在が認められている。この $\mathrm{P}-450$ は薬物や化学物質の活性化と不活性 化に関与しており，動物の種類，性，年齢およびその状態によって，ミクロソームに存在する分子種が異なり， 各種の薬物や環境污染物質によって選択的に誘導されるという性質をもっている。

$\mathrm{AFB}_{1}$ の代謝活性化は，その本体である $\mathrm{AFB}_{1}-8,9$-エポキシドが不安定で測定が困難なため，チフス菌の突 然变異を誘発させる変異原性能と, 癌化のイニシエーションに深く関係する細胞内 DNA と $\mathrm{AFB}_{1}$ の結合能が 指標として用いられている。

変異原性能を指標とした場合, $\mathrm{AFB}_{1}$ の変異原性は, ハムスターとモルモットの肝で最も強く, 次いでラッ ト, マウスの順で, その比率は $3: 1.7: 1$ である ${ }^{15)}$ 。肝細胞でも, $\mathrm{AFB}_{1}$ の変異原性はハムスターで最も強く, ラットとヒトはほぼ同様であるが, ヒト肝細胞ではラットより弱い組織変化が観察されている161。これらの結 果は, 染色体異常やSister chromatid exchange test の結果ともほぼ一致することが示されている ${ }^{17.18)}$ 。薬物代 謝酵素の誘導剂であるポリ塩化ビフェニル（PCB）の処置は, 各動物, 特にハムスター肝における $\mathrm{AFB}_{1}$ の変 異原性能を強く誘導する ${ }^{15)}$ 。精製された各種 P-450 分子種による $\mathrm{AFB}_{1}$ の変異原性能は, 3-メチルコラントレ ン $(\mathrm{MC})$ 処置したハムスター肝から得られた $\mathrm{P}-450_{\mathrm{AFB}}$ 分子種が最も強く, 同様の処置をしたラットから得ら れた主要な P-450の50倍の代謝活性化能を有することを, Mizokamiらが報告している191。またIshii らや Robertson ら ${ }^{20.211}$ は, $\mathrm{PCB}$ 処置したラットや無処置雄ラットから得られた $\mathrm{P}-450$ 等の変異原性能の強さを比較 しているが, これらの研究者が報告している結果は, P-450 male $>\mathrm{MC}$ 型P-450>PB 型 P-450とほぼ一致して いる。最近 Shimada らは, MC あるいはフェノバルビタール（PB）処置ラットから得られた $\mathrm{P}-450$ 分子種よ ク, 無処置の雄ラットから得られた $\mathrm{P}-450$ や雌ラットから得られた数種の $\mathrm{P}-450$ に, $\mathrm{AFB}_{1}$ の強い変異原性が あることを明らかにしている22!。

$\mathrm{AFB}_{1}$ の代謝活性化を $\mathrm{AFB}_{1}$ と $\mathrm{DNA}$ の結合能からみると, 肝スライスにおいてラットで最も強く, 次いで八 ムスター, マウスの順で, その比率は 24 28:9:1である23!。また, 分離肝細胞においては, ラットで最も 強く, 次いでヒト，マウスの順であることが報告されている24.25!。肝ミクロソームにおける $\mathrm{AFB}_{1}$ と DNA の 結合能は, 系統, 性あるいは年齢によって差がみられ, ラットに拈いては, Fischer系が Sprague Dawley 系よ $り^{261}$, 雄が倠より ${ }^{261}$, 老齢ラットが若いラットより強い27。 AFB1-DNA 結合は, ラットではPB やエタノール 処置によって誘導される ${ }^{28.29}$ が, 八ムスターではPBによる誘導はわずかで, エタノールや $16 \alpha-$ シアノプレグ ネノロン（PCN）ではむしろ減少し, MC， $\alpha$-ナフトフラボンおよびベンゾ（a ）ピレンなどの MC 型の誘導 剤によって極めて強く誘導される30)。 $\mathrm{AFB}_{1}-\mathrm{DNA}$ 結合能については, 肝より精製された $\mathrm{P}-450$ 分子種によって も検討されており，ラットでは PBやPCBによって誘導される $\mathrm{P}-450$ によって強く代謝活性化される $\mathrm{MC}$ によって誘導されるラットP-450による活性は低い ${ }^{17) 。 八 ム ス タ ー の ~} \mathrm{P}-450_{\mathrm{AFB}}$ は高い活性を示している ${ }^{199}$

$\mathrm{AFB}_{1}$ の代謝活性化に関与する因子としては，P-450への電子供給系の一因子であるチトクローム $\mathrm{b}_{5}{ }^{17}$ ，ま た, ミクロソームの $\mathrm{P}-450$ 以外の系による $\mathrm{AFB}_{1}$ の代謝活性化として, 肝の核における活性化年やアプロスタグ 
ランジンシンターゼの作用による $\mathrm{AFB}_{1}-8,9$-エポキシドの生成 ${ }^{31}$ などが報告されている。

\section{VI. アフラトキシン $\mathrm{B}_{1}$ の不活性化}

$\mathrm{AFB}_{1}$ の不活性化の 1 つに, P-450系による毒性の低い $\mathrm{AFM}_{1}, \mathrm{AFQ}, \mathrm{AFP}$ や $\mathrm{AFB}_{2 \mathrm{~A}}$ への代謝と, それに 続くグルクロン酸やタウロコール酸との抱合反応があげられる。抱合体は尿中へ，あるいは胆汁を介して糞中

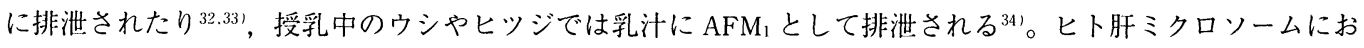
いて， $\mathrm{AFB}_{1}$ は主に $\mathrm{AFQ}_{1}$ へ代謝され， $\mathrm{AFM}_{1}$ への代謝は極めて少ない35!。ラット肝ミクロソームにおいて， $\mathrm{AFB}_{1}$ の不活性化は $\mathrm{AFB}_{1}$ から $\mathrm{AFM}_{1}$ あるいは $\mathrm{AFQ}_{1}$ への代謝が主な経路であるが, その比率は系統, 年䟻に よって異なっている36.37。 $\mathrm{AFB}_{1}$ から $\mathrm{AFQ}_{1}$ への代謝においては性差が認められ，雄ラットは雌の約 3 倍強い36。

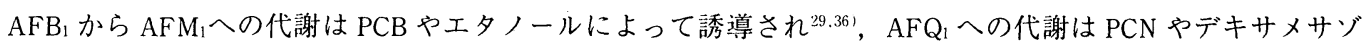
ンによって誘導される37。 $\mathrm{AFB}_{1}$ の不活性化に関与する $\mathrm{P}-450$ の分子種については, 現在のところラットにお いてのみ明らかにされているが， $\mathrm{AFB}_{1}$ から $\mathrm{AFM}_{1}$ への代謝には， $\mathrm{MC}$ や $\mathrm{PCB}$ で誘導される $\mathrm{P}-450$ が17，また， $\mathrm{AFQ}_{1}$ への代謝には $\mathrm{MC}, \mathrm{PB}$ および $\mathrm{PCN}$ で誘導される $\mathrm{P}-450$ 分子種の関与が明らかにされている17.37。

一方，P-450によって代謝活性化された $\mathrm{AFB}_{1}-8,9$-エポキシドは, 肝細胞質のグルタチオン $\mathrm{S}$ ートランスフ エラーゼ（GST）によって，グルタチオン（GSH）と抱合して，8-(S-glutathionyl)-9-hydroxy-8,9-dihydro

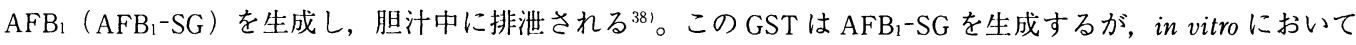
は, $\mathrm{AFB}_{1}-8,9$-エポキシドを基質とした場合，マウスではラットの約52倍の高い活性を示し391，ハムスターや モルモットもラットより高いGST 活性を示す40 421。ヒトにおいてはマウスの数10倍であることが観察されて いる35!。GSTには分子多様性が認められているが, ラット肝に存在する 6 種類の分子種のうち, $\mathrm{AFB}_{1}-8,9-$ -

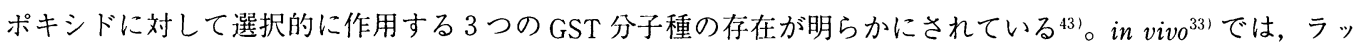
トに ${ }^{3} \mathrm{H}-\mathrm{AFB}_{1}$ あるいは ${ }^{14} \mathrm{C}-\mathrm{AFB}_{1}$ を腹腔内投与すると，1 時間後には無処置群では投与量の $21 \% か ゙ ， P B$ 前処置 群では投与量の $35 \%$ が胆汁中に排泄される。全群において尿中への排泄は, $\mathrm{AFB}_{1}$ 投与量の $2 \%$ \%下であった。

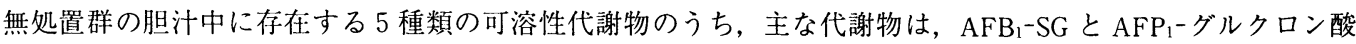
抱合体でそれぞれ胆汁中の $\mathrm{AFB}_{1}$ 代謝物の $49 \%$ と $4 \%$ を占める。PB の投与は, 肝の GSH 量, GST 活性, 胆汁 中への $\mathrm{AFB}_{1}-\mathrm{SG}$ 排泄速度を増加させ, $\mathrm{AFB}_{1}-\mathrm{DNA}$ 結合を減少させるが, 肝の $\mathrm{AFB}_{1}$ 残存量や胆汁中の $\mathrm{AFB}_{1}$ 代 謝物の構成には影響を与えない33!。

\section{V. アフラトキシン $B_{1}$ と毒性発現}

$\mathrm{AFB}_{1}$ の毒性発現は, 動物の種類, 系統, 性などによって異なり, 肝癌の発生は, マウスゃハムス夕ーより

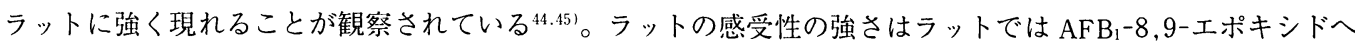
の代謝活性化能が高いこと, 活性化体を不活性化するGST 活性がマウスに比べて $1 / 52$ と極めて低く, $\mathrm{AFB}_{1}-\mathrm{DNA}$ 結合体の生成がマウスより多いことからも説明できる。また $\mathrm{PB}$ は, ラットでAFB $の$ 肝癌発生を 抑えることが知られている 導するため, 組織中の $\mathrm{AFB}_{1}$ 活性体が減少することによると推察される。また雄ラットが雌ラットより毒性の 発現が強いのは年，雄ラットに $\mathrm{AFB}_{1}$ を強く代謝活性化する $\mathrm{P}-450$ 種が見出されることに由来すると推察され る。以上より， $\mathrm{AFB}_{1}$ の毒性発現は，主に $\mathrm{AFB}_{1}$ の $\mathrm{P}-450$ による代謝活性化と，P-450と GSTなどによる不活 性化の 2 つ系のバランスに依存していることが明らかである。 
ハムスターはラットに比べ， $\mathrm{AFB}_{1}$ の肝癌発生や毒作用の発現が低いと考えられているが，MC を前処置し たハムスターに $\mathrm{AFB}_{1}$ を投与すると $\mathrm{AFB}_{1}$ 投与後 3 日目に全て死亡することにより，MCによって誘導される $\mathrm{P}-450$ 分子種が $\mathrm{AFB}_{1}$ の毒性発現に深く関わっている結果が得られている ${ }^{48)}$ 。したがって，MC型の誘導を示 す多くの環境污染物質には， $\mathrm{AFB}_{1}$ の毒性発現を促進する危険性のあることが示唆される。

また，日常的に使用される化学物質，たとえばエタノールはラットにおいて $\mathrm{AFB}_{1}$ の代謝活性化を誘導する ため ${ }^{291}$, 飲酒は $\mathrm{AFB}_{1}$ による発癌を促進する可能性も考えられる。そこで今後は, $\mathrm{AFB}_{1}$ の代謝活性化ととも に不活性化に関与する $\mathrm{P}-450$ 分子種, $\mathrm{AFB}_{1}-8,9$-エポキシドに選択的な GST 分子種, そして誘導剤の影響な どについて, ラット以外の動物種をも含めて, 細胞, 臓器および whole animal のレベルでの詳細な研究を行 う必要性があると思われる。 $\mathrm{AFB}_{1}$ の毒性発現の解明には, P-450や GST 等の機構のみで説明されるわけでは なく, $\mathrm{AFB}_{1}-\mathrm{DNA}$ 結合と肝の核や仁小体における RNA 合成阻害との関連性 ${ }^{49}, \mathrm{AFB}_{1}$ 活性化体のヒストン $\mathrm{H}_{1}$ 修飾 ${ }^{50)}, \mathrm{AFB}_{1}$ の血液凝固機能との関連 ${ }^{511}$ など, 多くの解明されるべき課題が残されている。

\section{おわりに に}

ヒトにおいて，最も死亡率の高い癌の 1 つである原発性の肝癌は, アジアやアフリカにおいて発症頻度が高

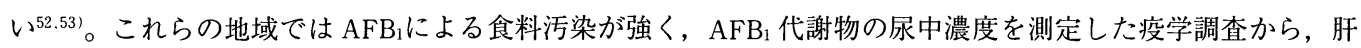
癌の原因の 1 つに $\mathrm{AFB}_{1}$ の摂取量との関係が考えられている ${ }^{54}$ 。 $\mathrm{AFB}_{1}$ の毒性発現は，主にチトクローム $\mathrm{P}-450$ による代謝活性化と，チトクローム P-450 アグルタチオン S-トランスフェラーゼなどによる不活性化とのバ ランスによって, ある程度説明されると思われるが, $\mathrm{AFB}_{1}$ の毒性発現には様々な因子が複雑にからみ合って おり，その解明にはさらに多くの研究が必要である。最近は $\mathrm{AFB}_{1}$ の代謝に関与するチトクローム $\mathrm{P}-450$ の遺 伝子構造の解明が行われつつあり， $\mathrm{AFB}_{1}$ の毒性発現機構が遺伝子レベルで解明されることが期待される。一 方, $\mathrm{AFB}_{1}$ の発癌を抑える抗酸化剂について研究がされている5 ${ }^{55}$ が, 抗酸化剂そのものが毒作用を有すること を考えると, $\mathrm{AFB}_{1}$ の毒性から身を守る最も有効な方法は, $\mathrm{AFB}_{1}$ による食品污染を防ぐことに尽きると思わ れる。また, 輸入食品のマイコトキシン検査を行っている機関としては, マイコトキシン検査協会（横浜）, また一般食品については, 各県の衛生研究所等がある。 $\mathrm{AFB}_{1}$ を含むマイコトキシンの食品污染の実態につい ては一戸らの報告に詳しく述べられている ${ }^{56.57) 。 ~}$

1) 上村 尚：フードケミカル，5，88９8（1988）

2) Yamazaki, M. : Chemistry of mycotoxins in toxicology, biochemistry and pathology of mycotoxins/ Uraguchi, K. and Yamazaki, M. eds., pp.65 (1978) John Wiley and Sons, New York

3) Enomoto, M. and Saito, M. : Annual Rev. Microbiol., 26, 279 -312 (1972)

4) Tsuboi, S., Nakagawa, T., Tomita, M., Soo, T., Ono, H., Kawamura, K. and Iwamura, N. : Cancer Res., 44, $1231 \sim 1234$ (1984)

5) Blount, W. P. : J. Br. Turkey Fed., 9, 52 77 (1961)

6) World Health Organization : Environmental health criteria, 11, pp.28 50 (1979) WHO Publications, Geneva

7) Mintzlaff, H. J., Lotsch, R., Touchmann, F., Meyer, W. and Listner, L. : Fleischwittscraft, 54, 774 778 (1974)

8) Garner, R. C., Miller, E. C. and Miller, J. A. : Cancer Res., 32, 2058 2066 (1972) 
9) Masri, M., Booth, A. N. and Hsieh, D. P. H. : Life Sci., 15, 203 212 (1974)

10) Patterson, D. S. P. and Roberts, B. A. : Food Cosmet. Toxicol., 8, 527 538 (1970)

11) Dalezios, J. I., Wogan, G. N. and Weinreb, S. M. : Science, 171, 584 585 (1971)

12) Salhab, A. S. and Edwards, G. S. : Cancer Res., 37, 1016 1021 (1977)

13) Wong, J. J. and Hsieh, D. P. H. : Proc. Natl. Acad. Sci. U.S.A., 73, 2241 2244 (1976)

14) Essigmann, J. M., Croy, R. G., Nadzan, A. M., Busby, W. F. Jr., Reinhold, V. N., Buchi, G. and Wogan, G. N. : Proc. Natl. Acad. Sci. U.S.A., 74, 1870 1874 (1977)

15）福原守雄, 策内桃子：昭和62年度環境保全研究成果集/環境庁企画調整局研究調整課編, pp.26-14 18 (1988)

16) Snyder, S., Hsu, I. C. and Trump, B. F. : Mutation Res., 182, $31 \sim 39$ (1987)

17) Ueno, Y., Tashiro, F. and Nakaki, H. : Gann Monograph Cancer Res., 30, 111 124 (1985)

18) Madle, E., Korte, A. and Beek, B. : Terat. Carcino. Mutagen., 6, 1 13 (1986)

19) Mizokami, K., Nohmi, T., Fukuhara, M., Takanaka, A. and Omori, Y. : Biochem. Biophys. Res. Commun., 139, 466 472 (1986)

20) Ishii, K., Maeda, K., Kamataki, T. and Kato, R. : Mutation Res., 174, 85 88 (1986)

21) Robertson, I. G. C., Zeiger, E. and Goldstein, J. A. : Carcinogenesis, 4, 93 96 (1983)

22) Shimada, T., Nakamura, S., Imaoka, S. and Funae, Y. : Toxicol. Appl. Pharmacol., 91, 13 21 (1987)

23 ) Booth, S. C., Bosenberg, H., Garner, S. C., Hertzog, P. J. and Norpoth, K. : Carcinogenesis, 2, $1063 \sim 1068$ (1981)

24) Hsu, I. C., Harris, C. C., Lipsky, M. M., Snyder, S. and Trump, B. F. : Mutation Res., 177, 1 7 (1987)

$25)$ Cole, E. K., Jones, T. M., Lipsky, M. M., Trump, B. F. and Hsu, I. C. : Carcinogenesis, 9, 711 716 (1988)

26) Plummer, S., Boobis, A. R. and Davies, D. S. : Xenobiotica, 17, 199 208 (1987)

27) Prasanna, H. R., Lotlikar, P. D., Hacobian, N. and Magee, P. N. : Cancer Lett., 33, 259 267 (1986)

28) Guengerich, F. P. : Biochem. Phamacol., 28, 2883 2890 (1979)

29) Toskulkao, C. and Glinsukon, T. : Toxicol. Lett., 30, 151 157 (1986)

30) Sunouchi, M., Fukuhara, M., Ohno, Y. and Takanaka, A. : J. Toxicol. Sci., 13, 193 204 (1988)

31) Battista, J. R. and Marnett, L. J. : Carcinogenesis, 6, 1227 1229 (1985)

32) Dalezios, J. I., Hsieh, D. P. H. and Wogan, G. N. : Food Cosmet. Toxicol., 11, 605 616 (1973)

33) Holeski, C. J., Eaton, D. L., Honroe, D. H. and Bellamy, G. M. : Xenobiotica, 17, 139 153 (1987)

34) Masri, M., Booth, A. N. and Hsieh, D. P. H. : Life Sci., 15, 203 212 (1974)

35) Moss, E. J. and Neal, G. E. : Biochem. Pharmacol., 34, 3193 3197 (1985)

36) Halvorson, M. R., Phillips, T. D., Safe, S. H. and Robertson, L. W. : Appl. Environ. Microbiol., 49, 882 886 (1985)

37) Halvorson, M. R., Safe, S. H., Parkinson, A. and Phillips, T. D. : Carcinogenesis, 9, 2103 2108 (1988)

38) Moss, E. J., Judah, D. J., Przyblyski, M. and Neal, G. E. : Biochem. J., 210, 227 233 (1983)

39) Monroe, D. H. and Eaton, D. A. : Toxicol. Appl. Pharmacol., 94, 118 127 (1988)

40) Lotlikar, P. D., Jhee, E. C., Insetta, S. M. and Clearfield, M. S. : Carcinogenesis, 5, 269 276 (1984)

41) Raj, H. G., Prasanna, H. R., Magee, P. N. and Lotlikar, P. D. : Cancer Lett., 33, 1 9 (1986)

42) Neal, G. E., Nielsch, U., Judah, D. J. and Hulbert, P. B. : Biochem. Parmacol., 24, 4269 4276 (1987)

43) Coles, B., Meyer, D. J., Ketterer, B., Stanton, C. A. and Garner, R. C. : Carcinogenesis, 6, 693 697 (1985)

44) Harrold, K. M. : Br. J. Cancer, 23, 655 660 (1969)

45) Gopalan, C., Tulpule, P. G. and Krishnamurthi, D. : Food Cosmet. Toxicol., 10, $519 \sim 523$ (1972)

46) Mclean, A. E. M. and Marshall, A. : Br. J. Exp. Pathol., 52, 322 329 (1971)

47) Bulter, W. H. : Aflatoxicosis in laboratory animals/ Goldblatt, L. ed., pp.223 236 (1969) Academic Press, New York 
48) Fukuhara, M., Sakaguchi, M., Inoue, S., Furukawa, F., Sunouchi, M., Takahashi, M. and Takanaka, A. : 19th Symposium on Drug Metabolism and Action, pp.102 105 (1988)

49) Yu, F. L., Geronimo, I. H., Bender, W. and Permthamsin, J. : Carcinogenesis, 9, 527 532 (1988)

50) Groopman, J. D., Busby, W. F., Jr. and Wogan, G. N. : Cancer Res., 40, 4343 4351 (1980)

51) Clark, J. D., Greene, C. G., Calpin, J. P., Hatch, R. C. and Jain, A. V. : Toxicol. Appl. Pharmacol., 86, 353 361 (1986)

52) Shank, R. C., Bhamarapravati, N., Gordon, J. E. and Wogan, G. N. : Food Cosmet. Toxicol., 10, $171 \sim 183$ (1972)

53) Van Rensburg, S. J., Cook-Mozaffari, P., Van Schalkwyk, D. J., Van der Watt, J. J., Vincent, T. J. and Purchase, I. F. : Br. J. Cancer, 51, 713 726 (1985)

54) Autrup, H., Seremet, T., Wakhisi, J. and Wasunna, A. : Cancer Res., 47, 3430 3433 (1987)

55) Iverson, F., Campbell, J., Clayson, D., Hierlihy, S., Labossiere, E. and Hayward, S. : Cancer Lett., 34, 139 〜144 (1987)

56）一戸正勝：遺伝， 40, 12〜17（1986）

57）山本勝彦：フードケミカル，5，78８7 (1988) 